\title{
ANALISIS EFEKTIVITAS PENYERTAAN MODAL NEGARA (PMN) TERHADAP KINERJA KEUANGAN PT WASKITA KARYA (PERSERO) TBK
}

Vijey Hamdani Yusuf Ikhsan

Politeknik Keuangan Negara STAN

E-mail : vjhamdani@gmail.com

\section{INFORMASI ARTIKEL \\ File Diterima: \\ [01 November 2021] \\ Revisi: \\ [10 November 2021] \\ Diterima: \\ [16 November 2021]}

Kata Kunci:

Penyertaan Modal Negara (PMN), Waskita Karya, Rasio Kinerja Keuangan

\section{ABSTRAK}

This study will show how the impact is given by State Capital Participation (PMN) on the financial performance of PT Waskita Karya. In this paper, Waskita's financial performance will be measured using a quantitative approach within various ratios, such as: liquidity ratios, solvability, activity, and profitability ratios. The data used in compiling these ratios were taken from Waskita's 2013 to 2017 audited financial statements. The financial report can be obtained from the official website of PT Waskita or Indonesia Stock Exchange (BEI) Website. The results showed that after the $P M N$, the profitability ratio increased and the liquidity ratio did not change significantly. Meanwhile, there was a decrease in the solvability ratio and the activity ratio.

Penelitian bertujuan menunjukkan bagaimana dampak yang diberikan oleh Penyertaan Modal Negara (PMN) terhadap kinerja keuangan PT Waskita Karya. Dalam penelitian ini, kinerja keuangan Waskita akan diukur dengan menggunakan pendekatan kuantitatif berupa berbagai macam rasio, antara lain: rasio likuiditas, solvabilitas, aktivitas, dan profitabilitas. Data yang digunakan dalam menyusun rasio-rasio tersebut diambil dari laporan keuangan Waskita tahun 2013 sampai dengan 2017 yang sudah diaudit. Laporan keuangan tersebut dapat diperoleh dari situs resmi PT Waskita ataupun situs resmi Bursa Efek Indonesia (BEI). Hasil penelitian menunjukkan bahwa setelah adanya PMN, rasio profitablitas mengalami kenaikan dan rasio likuiditas tidak mengalami perubahan signifikan. Sementara itu, terjadi penurunan pada rasio solvabilitas dan rasio aktivitas. 
Vijey Hamdani Yusuf Ikhsan

\section{PENDAHULUAN}

\subsection{Latar Belakang}

Salah satu upaya untuk memperoleh keuntungan yang banyak dan menyejahterakan rakyat adalah dengan cara dibentuknya Badan Usaha Milik Negara (BUMN) oleh Pemerintah Pusat. BUMN sendiri merupakan badan usaha yang $51 \%$ lebih sahamnya dimiliki oleh Pemerintah Pusat sehingga Pemerintah Pusat memiliki kewenangan yang besar untuk mengaturnya (Kompas, 2021). Meskipun Pemerintah Pusat dapat membiayai BUMN melalui APBN, Pemerintah Pusat tidak boleh sewenang-wenang dalam mengatur BUMN dikarenakan terdapat banyak stakeholder atau pemangku kepentingan lain selain Pemerintah Pusat yang juga ikut dalam tubuh BUMN. Karena memiliki regulasi yang berbeda, oleh karena itulah BUMN termasuk Kekayaan Negara Dipisahkan (KND).

Meskipun 51\% lebih sahamnya dikuasai oleh Pemerintah Pusat, namun belum tentu BUMN dapat bekerja secara optimal. Beberapa di antaranya sudah rugi selama bertahun-tahun, ada yang masih merugi selama1 dekade, ada juga yang tetap merugi selama seperempat abad (CNBC Indonesia, 2020). Ada juga BUMN yang memiliki masalah kepegawaian, ada yang sudah memonopoli pasar namun masih merugi, dan masih banyak lagi kasus lainnya. Hal ini disebabkan banyak faktor, baik dari kinerja internal yang kurang baik, maupun adanya perusahaan swasta dan asing yang menciptakan produk yang lebih baik dibandingkan dengan produk BUMN tersebut.

Berbagai kondisi seperti inilah yang menyebabkan pemerintah harus turun tangan untuk menyelamatkan kelangsungan hidup dari BUMN tersebut. Cara-cara yang ditempuh pemerintah pun cukup beragam dan bermacam-macam. Beberapa di antaranya berupa pencairan utang pemerintah atau kompensasi BUMN, PMN, serta dana talangan (Katadata, 2020). Segala cara akan diupayakan dan diusahakan oleh pemerintah agar BUMN bisa terselamatkan atau bahkan bisa memperoleh keuntungan yang lebih besar dibandingkan dengan kinerja tahun sebelum-sebelumnya.

Salah satu dari sekian BUMN yang pernah bermasalah adalah PT Waskita Karya (Persero) Tbk. Sebagai salah satu pemain utama di bidang industri jasa konstruksi, Waskita pernah ditugaskan oleh pemerintah untuk mengambil alih dan menyelesaikan banyak pembangunan tol di Trans-Jawa milik swasta yang mangkrak atau lambat penyelesaiannya pada 20152016 (Katadata, 2021). Banyaknya pembangunan itulah yang mengakibatkan kondisi keuangan PT Waskita kurang stabil sehingga pemerintah memutuskan untuk memberikan PMN pada tahun 2015 kepada PT Waskita Karya. Pada kesempatan kali ini, Penulis sendiri akan mencoba fokus untuk membahas Penyertaan Modal Negara (PMN) yang dilakukan Pemerintah Pusat terhadap PT Waskita Karya pada tahun 2015 sehingga keuangannya membaik dan juga berdampak pada kelangsungan hidup perusahaannya.

Menurut Peraturan Pemerintah (PP) No. 72 tahun 2016 tentang perubahan atas PP No. 44 tahun 2005 tentang Tata Cara Penyertaan dan Penatausahaan Modal Negara Pada Badan Usaha Milik Negara dan Perseroan Terbatas, Penyertaan Modal Negara (PMN) adalah pemisahan kekayaan negara dari Anggaran Pendapatan dan Belanja Negara atau penetapan cadangan perusahaan atau sumber lain untuk dijadikan sebagai modal BUMN dan/atau Perseroan Terbatas lainnya, dan dikelola secara korporasi.

PMN pada PT Waskita Karya sendiri diatur dalam PP No. 29 tahun 2015 tentang penambahan penyertaan modal Negara Republik Indonesia ke dalam modal saham perusahaan perseroan (Persero) PT Waskita Karya Tbk. Dalam Peraturan Pemerintah tersebut dinyatakan bahwa Pemerintah Pusat menggelontorkan dana sebesar Rp3,5 Triliun untuk membantu PT Waskita Karya.

Karena itulah, implementasi PMN pada PT Waskita Karya ini sangat menarik untuk dibahas dalam rangka mengetahui seberapa besar dampak kontribusi yang diberikan oleh PMN terhadap kinerja keuangan perusahaan yang diberitakan sempat mengalami permasalahan tersebut.

\section{KERANGKA TEORI}

\subsection{Konsep Penyertaan Modal Negara}

Berdasarkan Peraturan Pemerintah No. 72 tahun 2016 tentang Perubahan atas Peraturan Pemerintah No. 44 tahun 2005 tentang Tata Cara Penyertaan dan Penatausahaan Modal Negara pada Badan Usaha Milik Negara dan Perseroan Terbatas, pengertian dari Penyertaan Modal Negara adalah pemisahan kekayaan Negara dari APBN atau penetapan cadangan perusahaan atau sumber lain untuk dijadikan sebagai modal BUMN dan/atau Perseroan Terbatas lainnya, dan dikelola secara korporasi . Berdasarkan pengertian ini, secara sederhananya kita dapat mengetahui bahwa PMN dapat dilakukan dengan cara antara lain melalui APBN, kapitalisasi cadangan, atau sumber lain yang sah, seperti keuntungan revaluasi asset atau agio saham.

PMN dilakukan negara dengan tujuan tertentu. Berdasarkan PP No. 44 tahun 2005, tujuan PMN adalah untuk memperbaiki struktur permodalan atau meningkatkan kapasitas kinerja dan usaha BUMN terkait. Selain itu hal tersebut juga dapat ditujukan untuk membantu BUMN dalam menyelenggarakan 
kegiatannya apabila mendapatkan tugas khusus dari pemerintah (Dinarjito, 2019). Jika ditinjau dari nota APBN tahun 2017, PMN memiliki tujuan untuk mendukung 14 pencapaian program pemerintah di bidang tertentu, mendukung tugas pokok dan fungsi pemerintah dalam BUMN, dan mendukung adanya upaya restrukturisasi BUMN.

Berdasarkan Peraturan Pemerintah No. 29 tahun 2015 tentang Penambahan Penyertaan Modal Negara Republik Indonesia ke dalam Modal Saham Perusahaan Perseroan (Persero) PT Waskita Karya Tbk, Pemerintah menyuntikkan dana untuk perusahaan ini sebesar 3,5 triliun. Dalam data yang disajikan dalam laporan keuangan PT Waskita Karya di tahun 2015, dana tersebut digunakan untuk membantu pembuatan konstruksi, khususnya untuk TOL di Pulau Sumatera.

\subsection{Analisis Kinerja Keuangan}

Untuk melakukan analisis kinerja keuangan suatu perusahaan, dapat dilihat melalui rasio keuangan. Rasio keuangan sendiri merupakan salah satu cara untuk menganalisa kuangan sebagai indikator penilaian sehat atau berkembangnya suatu perusahaan dengan cara menggunakan data yang terdapat pada laporan keuangan selama periode akuntansi (Kumparan, 2021). Rasio keuangan sendiri memiliki beberapa macam, seperti berikut:

\section{a. Rasio Likuiditas}

Rasio ini menggambarkan tentang seberapa likuid sebuah perusahaan. Perusahaan dapat dikatakan likuid apabila aktiva lancarnya dapat digunakan untuk memenuhi kewajiban/utang jangka pendek. Rasio likuiditas terdiri dari beberapa unsur, antara lain:

\section{1) Current Ratio}

Rumus Current Ratio $=\frac{\text { Aktiva Lancar }}{\text { Utang Lancar }}$

Current Ratio atau biasa juga disebut dengan rasio lancar adalah rasio yang membandingkan seluruh aset lancar dengan kewajiban atau utang jangka pendek. Apabila rasio ini bernilai $>1$ atau lebih dari $100 \%$, maka dapat diartikan bahwa perusahaannya memiliki kemampuan untuk melunasi kewajiban lancar tanpa menganggu aktivitas perusahaan yang berjalan. Semakin tinggi nilai dari Current Ratio, maka semakin baik dan semakin likuid sebuah perusahaan.

\section{2) Quick Ratio}

Rumus Quick Ratio $=\frac{\text { Aktiva Lancar-Persediaan }}{\text { Utang Lancar }}$

Tidak jauh berbeda dengan Current Ratio, Quick Ratio juga berfungsi untuk menentukan seberapa likuid suatu perusahaan dengan cara membandingkan antara aktiva lancar tanpa persediaan dengan utang lancar. Hal ini dikarenakan persediaan relatif sukar untuk dijadikan kas atau setara kas. Apabila rasio menunjukkan hasil $>1$ atau lebih dari $100 \%$, maka perusahaan dianggap mampu untuk melunasi utang jangka pendeknya. Semkain tinggi nilai rasionya, maka semakin likuid sebuah perusahaan.

\section{3) Cash Ratio}

Rumus Cash Ratio $=\frac{\text { Kas atau Setara } \text { Kas }}{\text { Utang Lancar }}$

Rasio ini menggambarkan seberapa besar kas perusahaan yang tersedia agar dapat membayar utang jangka pendek. Cash Ratio ini adalah rasio yang menunjukkan kemampuan sebenarnya dari perusahaan untuk membayar utang lancarnya dikarenakan kas sangat likuid apabila dibandingkan dengan aset yang lain. Semakin besar nilai rasio ini, maka semakin besar kemampuan perusahaan untuk melunasi kewajiban jangka pendeknya menggunakan kas.

\section{b. Rasio Solvabilitas}

Rasio solvabilitas adalah rasio yang digunakan untuk mengukur sejauh mana aktiva perusahaan dibiayai dengan utang (Kasmir \& Jakfar, 2012). Jenis-jenis rasio solvabilitas adalah sebagai berikut:

\section{1) Debt to Assets Ratio}

Rumus $=\frac{\text { Total Utang }}{\text { Total Aktiva }}$

Dapat dilihat dari perhitungannya bahwa rasio ini membandingkan antara utang yang dimiliki perusahaan dengan asetnya. Secara sederhananya, rasio ini menjawab pertanyaan seberapa besar aset atau aktiva yang berasal dari utang. Semakin besar rasio ini menunjukkan bahwa proporsi utang yang menjadi sumber pembiayaan atas aset perusahaan juga lebih banyak.

2) Debt to Equity Ratio

Rumus $=\frac{\text { Total Utang }}{\text { Total Ekuitas }}$

Rasio Debt to Equity menggambarkan seberapa besar perbandingan antara utang yang dimiliki perusahaan dengan ekuitasnya. Dari sini kita dapat menarik kesimpulan bahwa apabila hasil rasionya menunjukkan angka 1, maka perusahaan memiliki jumlah utang dan ekuitas yang sama. Apabila nilainya 1 , maka pembiayaan perusahaan tersebut didominasi oleh utang.

\section{c. Rasio Aktivitas}

Rasio Aktivitas adalah rasio yang mengukur tingkat efisiensi dan efektivitas pemanfaatan sumber daya perusahaan (Orniati, 2009). Rasio ini juga menggambarkan bagaimana cara perusahaan terkait dapat memaksimalkan asetnya untuk menghasilkan profit yang maksimal. Beberapa contoh rasio aktivitas adalah seperti berikut: 
1) Total Asset Turnover

Rumus $=\frac{\text { Penjualan }}{\text { Total Aktiva }}$

Rasio Total Asset Turnover mendeskripsikan banyaknya jumlah penjualan yang dihasilkan dari setiap uang yang diinvestasikan dalam total aset perusahaan (Titman et al., 2018). Semakin tinggi angka dari rasio ini mengindikasikan bahwa semakin cerdasnya perusahaan dalam memanfaatkan asetnya untuk memperoleh pendapatan.

\section{2) Fixed Asset Turnover}

Rumus $=\frac{\text { Penjualan }}{\text { Aktiva Tetap }}$

Sama seperti Rasio Total Asset Turnover, Rasio Fixed Asset Turnover juga merepresentasikan seberapa efektif dan efisien perusahaan menggunakan asetnya untuk memperoleh profit. Bedanya adalah Fixed Asset Turnover Ratio hanya menggunakan aset tetap dalam perhitungannya. Semakin besar angkanya menunjukkan semakin bagus sebuah perusahaan mengelola aset tetapnya.

\section{3) Working Capital Turnover}

Rumus $=\frac{\text { Penjualan }}{\text { Modal Kerja Bersih }}$

Rasio Working Capital Turnover adalah tolok ukur yang digunakan untuk mengetahui atau menilai tingkat keefektivan modal kerja perusahaan dalam periode tertentu untuk meningkatkan profit dimana Net Working Capital sendiri merupakan selisih antara aset lancar dan utang lancar (Kasmir \& Jakfar, 2012). Ketika nilai rasio ini rendah atau bahkan negatif, maka perusahaan perlu mengevaluasi kinerjanya dikarenakan kurang memanfaatkan aset lancarnya

\section{d. Profitabilitas}

Profitabilitas adalah kumpulan-kumpulan rasio yang berfungsi untuk menghitung kemampuan suatu perusahaan dalam menghasilkan laba. Hal yang memengaruhi profitabilitas adalah bagaimana cara perusahaan dalam melakukan pengendalian biaya yang dikeluarkan dan bagaimana cara perusahaan dalam mengelola aktiva atau aset yang dimiliki.

\section{1) Gross Profit Margin (GPM)}

Rumus $=\frac{\text { Laba } \text { Kotor }}{\text { Penjualan }}$

Rasio GPM mendeskripsikan kapabilitas suatu perusahaan untuk mengontrol biaya usaha. Apabila nilai rasionya semakin mendekati angka 1, maka semakin kecil pula biaya usaha yang diperlukan perusahaan. Hal ini berarti Perusahaan sudah memiliki kontrol biaya yang apik dan ciamik. Sebaliknya, apabila nilainya kecil dan jauh dari angka 1, hal itu berarti beban usahanya terlalu besar sehingga profit yang didapatkan juga semakin kecil.
2) Net Profit Margin (NPM)

Rumus $=\frac{\text { Laba Bersih }}{\text { Penjualan }}$

Rasio NPM mengukur seberapa besar pendapatan sebuah perusahaan yang didapatkan atas penjualan yang dihasilkan sesudah disesuaikan dengan semua beban perusahaan (Titman et al., 2018). Semakin tinggi angkanya, maka dapat diketahui bahwa perusahaan tersebut mampu membukukan margin pendapatan bersih yang tinggi serta indikator yang menandakan bahwa perusahaan sudah berada pada jalur yang tepat karena keefektivan pengelolaan manajemen.

\section{3) Return on Asset (ROA)}

Rumus $=\frac{\text { Laba Bersih }}{\text { Total Aktiva }}$

Rasio ROA menunjukkan seberapa efisien aset yang dimiliki perusahaan dalam menghasilkan laba. Cara menghitunganya cukup dengan membandingkan laba bersih dengan total aset yang dimiliki perusahaan. Semakin tinggi nilainya, maka semakin bagus untuk perusahaan karena mengindikasikan bahwa perusahaan tersebut sangat optimal dalam memanfaatkan asetnya untuk menghasilkan profit.

4) Return on Equity (ROE)

Rumus $=\frac{\text { Laba Bersih }}{\text { Total Ekuitas }}$

Tidak jauh berbeda dengan ROA, ROE juga menunjukkan seberapa efisien sumber daya yang dimiliki perusahaan dalam menghasilkan laba. Jika ROA melibatkan aset perusahaan, maka ROE melibatkan ekuitasnya. Dari sini kita bisa tahu seberapa efisien ekuitas yang dimiliki perusahaan dalam menghasilan profit. Semakin tinggi nilainya maka semakin menunjukkan bahwa ekuitas perusahaan sudah dikelola secara baik.

\section{5) Operating Profit Margin (OPM)}

Rumus $=\frac{\text { Laba Bersih }}{\text { Penjualan }}$

OPM didapatkan dengan cara membagi EBIT dengan total penjualan, dimana EBIT merupakan kepanjangan dari Earning Before Interest and Taxes. Rasio OPM merepresentasikan seberapa banyak profit yang dihasilkan dari tiap penjualannya setelah dikurangi dengan beban usaha dan beban operasional. Apabila nilainya mendekati 1 , artinya biaya kontrol yang dimiliki oleh perusahaan tersebut sudah bagus. Namun apabila nilainya jauh dari angka 1 , berarti ada beban operasional yang cukup besar sehingga perusahaan memiliki operating income yang sedikit.

\section{METODE PENELITIAN}

Studi kepustakaan dalam penelitian ini dilakukan dengan menggunakan metode penelitian kuantitatif 
deskriptif. Metode penelitian kuantitatif adalah metode penelitian yang didasarkan pada filsafat positivisme, digunakan untuk meneliti pada populasi atau sampel tertentu, dan datanya dikumpulkan melalui instrument penelitian, serta analisis data bersifat kuantitatif atau statistik (Sugiyono, 2017). Sementara itu, penelitian deskriptif berusaha mendeskripsikan peristiwa yang memusatkan penelitian tanpa memberikan perlakuan khusus terhadap suatu peristiwa (UNM, 2018). Jadi, nantinya Penulis akan mengolah data berupa angka yang tentunya akan dideskripsikan atau dijelaskan.

Telaah juga dilakukan terhadap literatur berupa media cetak dan juga literatur yang ada di internet tentang PMN untuk mendukung dan menunjang data dan dokumen yang terkait dengan PMN yang dilakukan terhadap PT Waskita Karya Tbk. Data yang diolah Penulis utamanya diambil dari laporan keuangan PT Waskita Karya tahun 2013 s.d. 2017 melalui situs https://www.idx.co.id/ (situs resmi Bursa Efek Indonesia) dan juga https://waskita.listedcompany.com/ (situs resmi PT Waskita Karya).

\section{HASIL PENELITIAN}

\subsection{Analisis Kinerja Keuangan Untuk Tiap Rasio a. Rasio Likuiditas}

\section{1) Current Ratio}

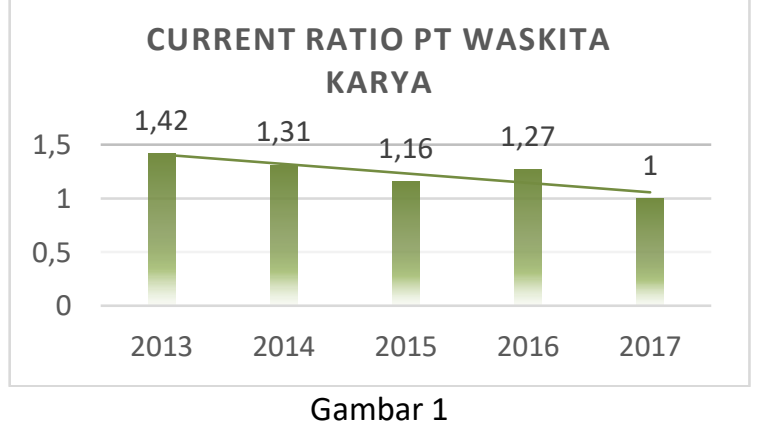

Pada tahun 2013 sampai dengan 2015, rasionya terlihat menurun. Namun karena pada tahun 2015 terjadi PMN, kejadian ini menyebabkan bertambah banyaknya aset PT Waskita Karya, termasuk aktiva lancar di dalamnya. Dana PMN yang diberikan oleh pemerintah digunakan untuk membangun jalan tol di Pulau Sumatera dan Jawa, serta untuk tambahan modal bagi perusahaan. Karena hal itu juga, pada tahun 2016 rasio ini sempat naik $9,48 \%$ dari poin 1,16 menuju 1,27.

Pada tahun 2017, liabilitas jangka pendek juga meningkat sebesar $67.2 \%$. Peningkatan ini disebabkan terutama oleh adanya kenaikan utang bank jangka pendek untuk proyek turnkey biaya yang masih diharuskan untuk dibayar. Selain itu juga terjadi peningkatan sebesar $91,5 \%$ dari segi utang usaha yang disebabkan karena adanya penambahan proyek yang diterima oleh PT Waskita. Lebih rincinya, meningkatnya liablitas jangka pendek perusahaan ini juga diakibatkan oleh adanya kenaikan pinjaman kepada Bank Mandiri, Bank BNI, dan Indonesia Exim Bank, yang digunakan untuk membiayai proyek turnkey.

\section{2) Quick Ratio}

QUICK RATIO PT WASKITA KARYA

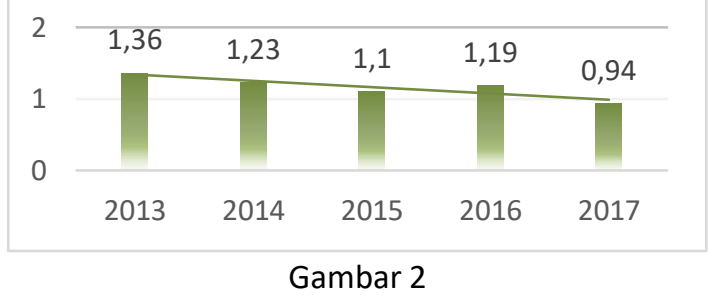

Garis trend Quick Ratio milik PT Waskita Karya tidak jauh berbeda dengan Current Ratio perusahaan ini, cenderung turun untuk tiap tahunnya. Pada tahun 2013 sampai dengan 2015 rasionya terlihat menurun dikarenakan pertumbuhan utang lancarnya lebih besar daripada pertumbuhan aktiva lancar. Dari sini dapat diketahui bahwa tingkat pertumbuhan persediaan (inventory) perusahaan Waskita cenderung stabil karena angka di Current Ratio selalu lebih besar jika dibandingkan dengan Quick Ratio.

Sama seperti nilai Current Ratio perusahaan ini, pada tahun 2016, Quick Ratio perusahaan ini juga sempat meningkat dikarenakan adanya PMN. Dana yang didapatkan dari PMN digunakan Waskita untuk membangun jalan tol di Jawa dan Sumatera, serta untuk penambahan modal perusahaan. Adanya aktivitas PMN membuat aset perusahaan bertambah banyak. Namun sayangnya, nilai rasio pada tahun berikutnya, yakni 2017, malah turun kembali.

Pada tahun 2017, diwartakan PT Waskita Karya melakukan kerja sama dengan PT Bank Panin Tbk. Dalam kerja sama ini, PT Waskita mendapatkan fasilitas pinjaman money market sebesar Rp2,5 triliun dengan garansi. Perjanjian ini juga mencakup hal-hal yang tidak diperbolehkan dilakukan oleh PT Waskita Karya tanpa persetujuan dari Bank Panin. Salah satu contohnya adalah menerima pinjaman atau kredit baru dari bank lain atau pihak ketiga yang jumlahnya dapat menyebabkan dilanggarnya rasio keuangan yang sudah disepakati. Nilai kontrak tiriliunan inilah yang menyebabkan naiknya liabilitas PT Waskita.

3) Cash Ratio 


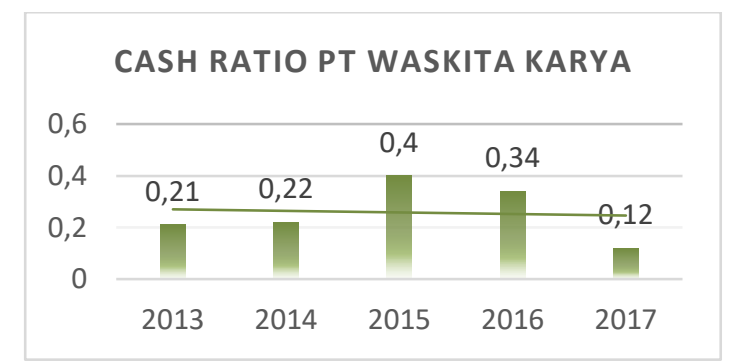

Gambar 3

Pada tahun 2015, aset lancar mengalami kenaikan sebesar $78,87 \%$ yang tentunya juga diakibatkan oleh meningkatnya saldo kas dan setara kas yang diperoleh dari hasil penawaran umum terbatas yang dilakukan untuk perusahaan, piutang usaha dari penjualan, dan uang muka dari biaya yang dibayar dimuka. Untuk akun kas dan setara kas sendiri mengalami kenaikan yang sangat signifikan bernilai 228,97\%. Pada 2014 nlainya berjumlah Rp1,6 triliun dan pada 2015 nilainya naik drastic menjadi Rp5,5 triliun.

Kemungkinan besar rasio ini juga dipengaruhi oleh PMN yang dilakukan pemerintah pada tahun 2015. Pemerintah menyuntikkan dana segara sebesar Rp3,5 triliun pada perusahaan Waskita agar kinerjanya semakin baik. Angka Rp3,5 triliun tentu bukan angka yang sedikit. Apabila dibandingkan dengan pendapatan PT Waskita pada tahun ini, jumlahnya setara dengan $25 \%$ revenue PT Waskita. Tentunya, PMN seringkali berbentuk fresh money agar lebih mudah untuk dihitung dan dimasukkan dalam neraca. Angka yang besar tersebut, tentunya menyebabkan naiknya nilai aset berupa kas dan setara kas milik PT Waskita Karya.

Setelah tahun 2015, rasio ini mulai menurun, bahkan pada tahun 2017, rasio ini berada pada titik terendah selama 5 tahun belakangan. Hal ini dikarenakan pada tahun tersebut aset kas dan setara kas bukannya bertambah, tapi malah berkurang. Pengurangannya berada pada kisaran angka -74\% dimana pada tahun 2016 aset ini berjumlah Rp10 triliun. Namun pada 2017, PT Waskita hanya memiliki kas dan setara kas senilai Rp6 triliun saja. Hal ini tentunya dapat menjadi bukti yang kuat bahwasanya PT Waskita mengalami penurunan pada Cash Ratio.

\section{b. Rasio Solvabilitas}

\section{1) Debt to Asset Ratio}

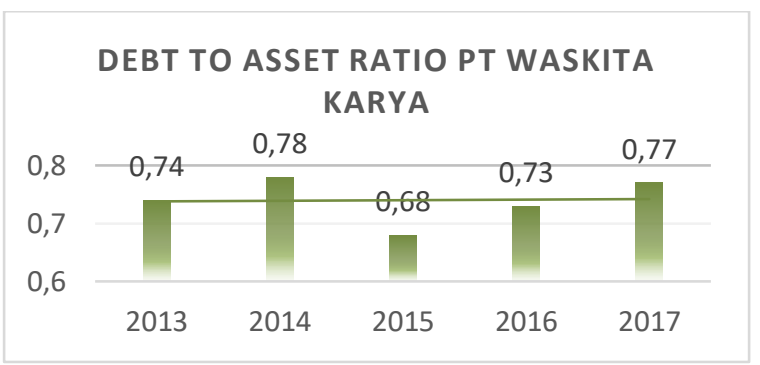

Gambar 4

Pada 2013 menuju 2014, rasionya meningkat sebesar 0,04 poin dari 0,74 menjadi 0,78 . Ini disebabkan oleh meningkatkan liabilitas Waskita yang semula dari Rp6,4 triliun menjadi Rp9,7 triliun. Pertumbuhan liabilitasnya mencapai $51,27 \%$ yang berarti pertumbuhannya lebih besar apabila dibandingkan dengan pertumbuhan ekuitas yang juga sama-sama memengaruhi jumlah aset. Pertumbuhan ekuitasnya hanya meningkat sebesar $18,01 \%$ yang semula nilainya $\mathrm{Rp2}, 3$ triliun menjadi Rp2,7 triliun.

Pada tahun 2015 juga terjadi peningkatan dari sisi liabilitas dibandingkan dengan tahun sebelumnya. Liabilitas jangka pendek naik hampir 2 kali lipat dari angka Rp7,7 triliun menjadi Rp13,6 triliun. Sedangkan liabilitas jangka panjang meningkat lebih dari 3 kali lipat dari angka 2 triliun menuju Rp6,9 triliun. Peningkatan liabilitas jangka panjang ini disebabkan oleh adanya peningkatan utang bank jangka Panjang, utang obligasi, dan utang jangka Panjang lainnya.

Meskipun demikian, pada tahun 2015, dapat diketahui bahwa nilai rasionya lebih rendah daripada 2 tahun sebelumnya, maupun 2 tahun setelahnya karena pada tahun ini terjadi peristiwa PMN sebesar Rp3,5 triliun dari pemerintah pusat, tentu saja hal ini berdampak pada bertambahnya aset perusahaan. Akibat adanya PMN, aset milik Waskita menjadi semakin banyak sehingga ketika dibandingkan dengan jumlah liabilitasnya, Debt to Asset Ratio perusahaan ini akan bernilai lebih kecil.

\section{2) Debt to Equity Ratio}

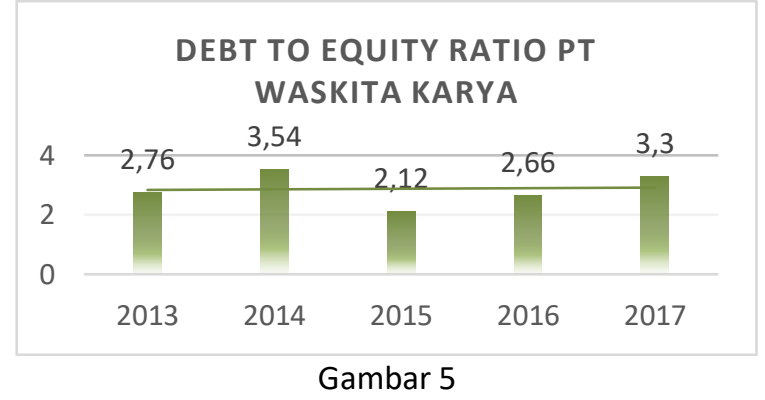

Tahun 2013 menuju 2014 digambarkan oleh grafik bahwa rasio ini mengalami peningkatan. Namun, pada tahun 2015 nilai rasionya turun sebesar $-40,11 \%$ dari 3,54 menjadi 2,12. Kemungkinan hal ini 
disebabkan oleh adanya peristiwa penting, yaitu PMN yang dilakukan oleh pemerintah kepada Waskita Karya. Dana sebesar Rp3,5 triliun yang disuntikkan menyebabkan adanya peningkatan ekuitas yang cukup tajam pada tahun tersebut. Ekuitas perusahaan ini sampai meningkat 251,08\% atau setara dengan 2,5 kali lebih banyak yang awalnya bernilai hanya $\mathrm{Rp} 2,7$ triliun menjadi Rp9,7 triliun. Karena tajamnya peningkatan ekuitas dan normalnya pertumbuhan liabilitas, membuat Debt to Equity Ratio PT Waskita pada tahun 2015 menjadi turun.

Selain adanya PMN, ekuitas Waskita meningkat drastis juga disebabkan karena adanya penawaran umum terbatas atau tambahan dana publik melalui mekanisme Rights Issue yang dibuka untuk umum. Gabungan antara PMN dengan tambahan dana publik membuat Waskita memiliki tambahan Rp5,8 triliun pada ekuitasnya.

\section{c. Rasio Aktivitas}

\section{1) Total Asset Turnover}

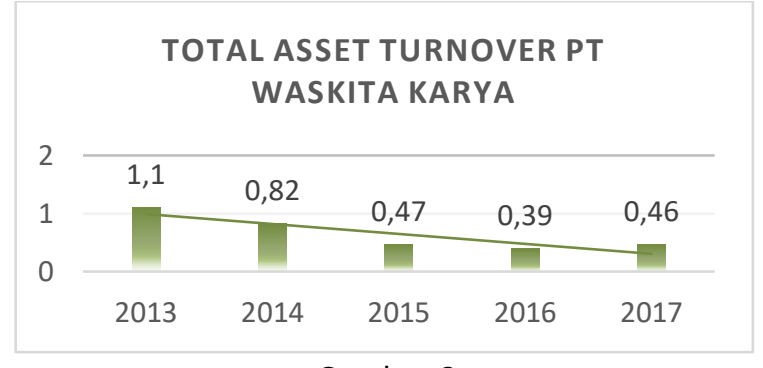

Gambar 6

2013 menjadi tahun dengan nilai rasio tertinggi dalam grafik di antara tahun yang lain. Dari grafik Total Asset Turnover milik PT Waskita dapat diketahui bahwa rasio ini memiliki garis trend yang menurun dari waktu ke waktu meskipun pada tahun 2017 terjadi peningkatan kembali nilainya sebesar 17,94\% menjadi 0,46 yang semula berasal dari 0,39. Penurunan nilai rasio terbesarnya terjadi pada tahun 2015 dari yang semula ada di titik 0,82 lalu menjadi 0,47 . Dari sini dapat diketahui bahwa telah terjadi penurunan sebesar $-42.68 \%$.

Bukan tanpa alasan, pada tahun 2015 terjadi penurunan paling dalam dikarenakan adanya PMN yang dilakukan pemerintah. Adanya tambahan dana sebesar 3,5 triliun tentu saja menyebabkan bertambahnya aset milik Waskita dengan cukup cepat. Karena pertumbuhan aset yang cukup cepat, sedangkan pertumbuhan sales perusahaan cukup wajar, maka tidak heran apabila terjadi penurunan rasio Total Asset Turnover yang cukup dalam.

Lebih rincinya, pada tahun 2015 terjadi peningkatan persentase kepemilikan aset Waskita sebesar
$141,66 \%$ menjadi Rp30 triliun yang semula hanya berjumlah Rp12,5 triliun. Sedangkan di sisi penjualan, persentase pertumbuhannya adalah $37,58 \%$ dari Rp10,2 triliun menjadi 14,1 triliun. Perbedaan pertumbuhan yang cukup jauh inilah yang tentunya membuat rasionya turun.

Pada tahun 2016 rasionya kembali mengalami penuruan, namun pada 2017, rasionya mulai bergerak naik. Kenaikan ini disebabkan oleh naiknya pendapatan PT Waskita yang hampir 2 kali lipat pada tahun 2016. Jadi, dapat disimpulkan adanya PMN pemerintah juga membuat pendapatan PT Waskita semakin meningkat karena setelah beberapa tahun terjadinya PMN, aset yang sudah selesai pembangunannya dapat digunakan untuk menambah pundi-pundi keuangan PT Waskita.

\section{2) Fixed Asset Turnover}

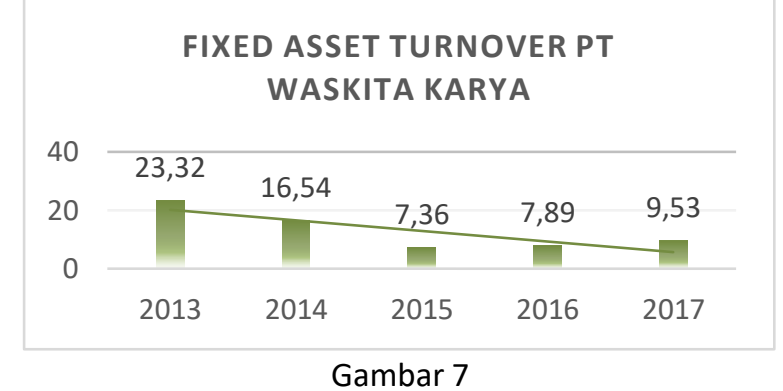

Pada tahun 2013, nilai rasio ini masih tinggi dikarenakan pada saat itu aset tetap perusahaan masih sangat sedikit, sedangkan penjualannya lebih besar apabila dibandingkan dengan aktiva tetapnya. Berlanjut pada 2014, nilai rasionya berkurang dikarenakan pertumbuhan penjualannya lebih kecil dibandingkan dengan pertumbuhan aktiva tetapnya. Penjualannya tumbuh 6,19\% sementara pertumbuhan aktiva tetapnya bernilai $49,66 \%$

Sama seperti kejadian pada rasio Total Asset Turnover, penurunan tajam pada rasio Fixed Asset Turnover juga disebabkan adanya PMN. Kucuran dana pemerintah sebesar Rp3,5 triliun ini tentunya juga membuat aset tetap perusahaan Waskita bertambah. Pada tahun 2015, terdapat kenaikan aset tetap sebesar 209,66\% dari yang awalnya bernilai Rp621 miliar menjadi Rp1,9 triliun. Kenaikan jumlah aset tetap pada tahun ini adalah yang terbesar apabila dibandingkan dengan tahun-tahun lain yang berada dalam grafik.

Selain adanya PMN, terdapat faktor lain yang menyebabkan naiknya aset tetap pada Perusahaan Waskita. Peristiwa tersebut adalah adanya selisih revaluasi atau penilaian kembali aset tetap milik Waskita. Akibat adanya kejadian ini, PT Waskita mendapatkan aset tetap tambahan sebesar Rp492 
miliar. Adanya peristiwa penting berupa PMN dari pemerintah lalu ditambah dengan adanya penilaian kembali aset milik perusahaan membuat aset tetap PT Waskita mengalami banyak kenaikan. Wajar halnya apabila di tahun ini, rasio Fixed Asset Turnover perusahaan tersebut turun cukup dalam.

\section{3) Working Capital Turnover}

\section{WORKING CAPITAL TURNOVER PT} WASKITA KARYA

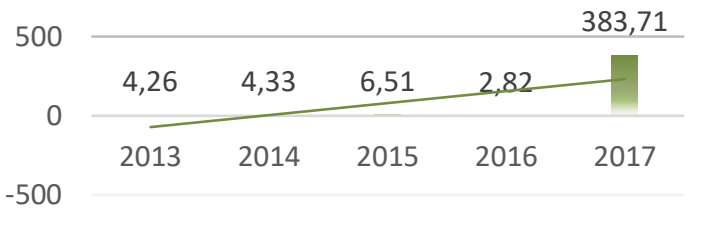

Gambar 8

Dapat diamati dalam grafik bahwa tidak ada perubahan besar nilainya dalam rentang waktu 2013 hingga 2016. Namun pada tahun 2017, nilai rasio ini meningkat dengan sangat tajam.

Berawal dari tahun 2016 dimana baik pada sisi aset lancar maupun sisi liabilitas lancar mengalami pertumbuhan yang cukup pesat, sehingga pada tahun 2017 keduanya memiliki jumlah yang hampir sama. Pada tahun 2016, aset lancar perusahaan Waskita meningkat 151,26\% dibandingkan tahun sebelumnya dimana nilainya menjadi Rp39,7 triliun yang awalnya hanya Rp15,8 triliun. Sedangkan pada sisi utang lancar juga meningkat sebesar 129,49\%. Keduanya tetap meningkat pada tahun 2017 sampai-sampai nilai antara keduanya hampir sama, yakni 52 triliun. Aktiva lancar perusahaan tersebut hanya selisih sedikit lebih banyak dibanding utang lancarnya.

Peningkatan pesatnya aset lancar milik Waskita disebabkan oleh adanya Initial Public Offering (IPO) atau melantainya anak Perusahaan PT Waskita Beton Precasat Tbk yang sukses mendapatkan dana segar sebesar Rp5,2 triliun dan hasil Penawaran Umum Berkelanjutan Obligasi Perseroan Tahap I dan II sebesar Rp2,9 triliun. Sementara itu, liabilitas perusahaan juga meningkat drastis dikarenakan adanya kenaikan pinjaman kepada Bank Mandiri, Bank BNI, dan Indonesia Exim Bank, yang digunakan untuk membiayai proyek turnkey.

Tidak cukup sampai disitu saja, peningkatan rasio ini menjadi sangat besar juga tidak lepas karena adanya PMN pada tahun 2015. Setelah dilakukannya PMN, disinyalir dalam 2 tahun berikutnya Perusahaan PT Waskita semakin mudah dan semakin lincah dalam mengelola perusahaannya sehingga mendapatkan banyak tambahan revenue. Pendapatan usaha terbanyak disumbangkan dari jasa kontruksi yang pada tahun 2017 mencapai nilai Rp42 triliun. Sedangkan pihak berelasi yang menyumbangkan pendapatan terbanyak untuk Waskita adalah PT Hutama Karya yang juga sama-sama bergerak dalam bidang konstruksi. PT Hutama Karya berkontribusi sebesar Rp6,4 triliun untuk pendapatan PT Waskita pada tahun 2017.

Karena adanya banyak faktor tersebut, tidak heran rasanya apabila pada tahun 2017 PT Waskita memiliki rasio Wokring Capital Turnover yang sangat melejit. Bahkan bisa dibilang angka dari rasio 2017 sangat tidak wajar apabila dibandingkan dengan rasio di tahun-tahun sebelumnya. Adanya peristiwa Initial Public Offering, kenaikan pinjaman pada banyak bank, dan kehadiran PMN adalah tiga hal utama yang membentuk angka rasio yang sangat tinggi tersebut.

\section{d. Rasio Profitabilitas}

1) Gross Profit Margin (GPM)

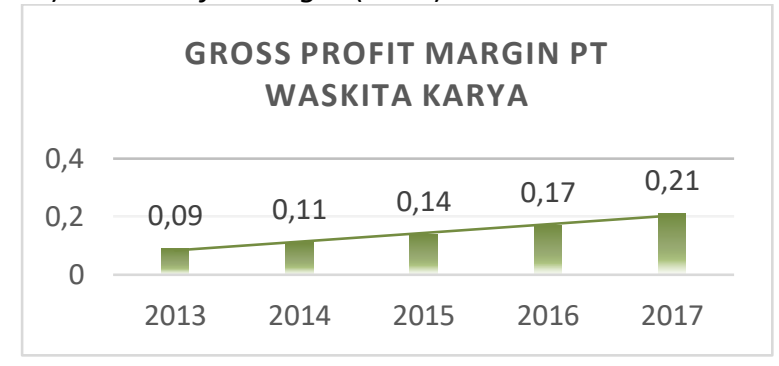

Gambar 9

Peningkatan laba kotor terbanyak terjadi pada tahun 2017. Saat itu gross profit keseluruhan PT Waskita Karya melesat sebesar 138,54\% dari angka Rp3,9 triliun menjadi Rp9,4 triliun karena terjadi kenaikan pada banyak segmen penjualan. Pada segmen konstruksi terjadi pertumbuhan sebesar $138,31 \%$ dari awalnya Rp3,5 triliun menjadi Rp8,5 triliun. Pada segmen sewa gedung terjadi pertumbuhan yang sangat tajam, yakin 633,9\% berada di angka Rp10,2 miliar padahal sebelumnya hanya berada pada angka Rp1,4 miliar. Terjadi juga kenaikan pada segmen penjualan beton precast sebesar $138,9 \%$ yang semula berada pada angka Rp255 miliar lalu menjadi Rp609 miliar. Kenaikan ini tentunya dialami oleh banyak segmen lainnya pada aktivitas yang dilakukan Perusahaan Waskita.

Pada tahun yang sama juga terjadi peningkatan sales revenue yang tinggi, yakni hingga mencapai $90 \%$ dari awalnya Rp23,7 triliun menjadi Rp45,2 triliun. Meskipun kenaikan pendapatannya mencapai $90 \%$, namun pertumbuhannya masih lebih kecil apabila dibandingkan dengan pertumbuhan laba kotor Waskita yang mencapai $138,54 \%$. Sebelum masuk pada tahun anggaran 2017, pertumbuhan laba kotor Waskita juga selalu lebih tinggi apabila dibandingkan 
dengan pendapatannya. Kejadian inilah yang menjadi bukti mengapa rasio Gross Profit Margin milik Waskita lebih tinggi dari tahun ke tahun disamping terdapatnya peristiwa PMN yang terjadi 2 tahun sebelumnya.

\section{2) Net Profit Margin (NPM)}

\section{NET PROFIT MARGIN PT WASKITA} KARYA

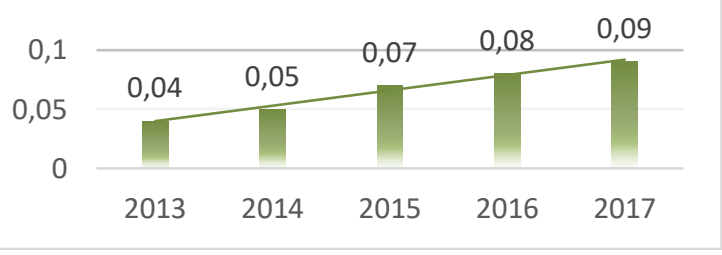

Gambar 10

Pertumbuhan tertinggi rasio ini terjadi pada tahun 2015 dimana terjadi kenaikan 0,02 dibanding tahun sebelumnya. Pada tahun tersebut PT Waskita mencatatkan pertumbuhan laba bersih sebesar Rp1 triliun, naik 104,78\% dibandingkan pada 2014 sebesar Rp511 miliar. Kenaikan rasio tertinggi yang terjadi pada tahun 2015 di antara tahun-tahun yang lain diindikasikan terjadi karena beban pokok pendapatan, beban bunga, dan pajak yang diterima PT Waskita pada tahun tersebut tidak terlalu tinggi.

Selain itu, pada tahun tersebut juga terjadi adanya peristiwa PMN dimana pemerintah memberikan dana segar sebesar Rp3,5 triliun bagi perusahaan. Dana tersebut juga turut digunakan PT Waskita untuk modal perusahaan serta pembangunan infrastruktur berupa tol yang ada di Jawa dan Sumatera. Adanya tambahan permodalan dari pemerintah inilah yang membuat Waskita memperoleh net profit lebih banyak karena perusahaan tersebut menempatkan $70 \%$ dari dana PMN untuk tambahan permodalannya, sedangkan $30 \%$ sisanya digunakan untuk pembangunan tol di Jawa dan Sumatera.

\section{3) Return on Asset (ROA)}

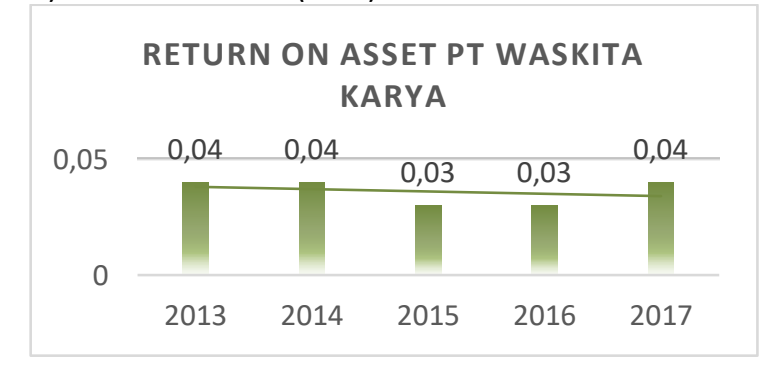

Gambar 11

Grafik ROA PT Waskita bersifat fluktuatif sehingga sempat turun lalu naik kembali. Namun dilihat dari grasi trend rasionya, rasio ROA cenderung menurun. Pada tahun 2013 ke 2014 rasio ROA perusahaan ini memiliki nilai yang sama. Dari peristiwa ini dapat diketahui bahwa antara laba bersih dan total aktiva perusahaan memiliki tingkat pertumbuhan yang sama.

Menurut laporan keuangan perusahaan PT Waskita, penyebab turunnya rasio sebesar 0,01 poin pada tahun 2015 adalah terjadinya peristiwa PMN. Karena aset perusahaan bertambah sebesar Rp3,5 triliun, membuat perbandingan antara laba bersihnya menjadi semakin kecil. Pertumbuhan laba bersih atau net profit yang cenderung biasa, lantas dibandingkan dengan nilai aset yang bertambah pesat karena adanya PMN sebesar Rp3,5 triliun jelas membuat nilai rasionya menjadi semakin kecil.

Adanya PMN sebesar Rp3,5 triliun juga menjadikan tahun 2015 sebagai tahun dengan pertumbuhan aktiva tertinggi dibandingkan dengan tahun-tahun yang lain yang ada dalam grafik. Pada tahun tersebut, jumlah total aktiva PT Waskita melesat tajam sebesar $141,66 \%$ menjadi Rp30 triliun yang semula hanya berjumlah Rp12,5 triliun. Pertumbuhan aset pada tahun ini juga disebabkan oleh adanya kenaikan kas dan setara kas sebesar $228,97 \%$. Kenaikan piutang usaha sebesar $101,74 \%$, dan kenaikan aset tetap sebesar 209,29\%.

\section{4) Return on Equity (ROE)}

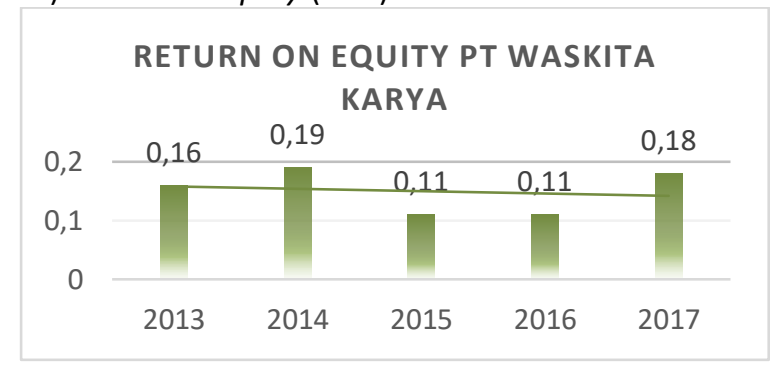

Gambar 12

Dana PMN sebesar Rp3,5 triliun yang digelontorkan pemerintah pada tahun 2015 juga menyebabkan tahun 2015 sebagai tahun dengan pertumbuhan ekuitas tertinggi dibandingkan dengan tahun-tahun lain yang ada dalam grafik. Pada tahun tersebut, jumlah ekuitas yang semula berada dalam angka $\mathrm{Rp} 2,7$ triliun naik pesat menuju angka Rp9,7 triliun sehingga ada kenaikan sebesar $251,08 \%$. Faktor lain yang menyebabkan adanya kenaikan ekuitas adalah adanya tambahan modal disetor melalui mekanisme Penawaran Umum Terbatas dan saldo laba. Jadi, selain terdapat PMN, PT Waskita juga mendapatkan tambahan modal dari masyarakat umum langsung.

Setahun setelah terjadinya PMN pada tahun 2015, angka dari rasio ROE juga masih belum bisa beranjak dari 0,11 , tetap sama seperti tahun sebelumnya. Hal ini mengindikasikan bahwa dampak yang ditimbulkan 
PMN cukup kuat sehingga mampu menekan angka rasio menjadi tidak bergerak sama sekali. Setahun berikutnya berselang, lebih tepatnya pada tahun 2017, akhirnya perusahaan berhasil menggerakkan angka rasio ini menjadi 0,18.

5) Operating Profit Margin (OPM)

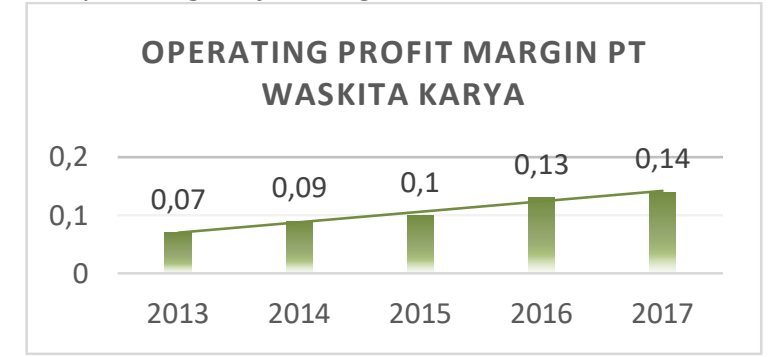

Gambar 13

PMN yang diberikan pemerintah berupa dana segar sebesar 3,5 triliun tidak bisa langsung dilacak dalam rasio ini dikarenakan PMN masuk dalam neraca perusahaan. Sementara itu, EBIT dan pendapatan usaha dapat dicari dalam laporan laba rugi perusahaan. Meskipun begitu, dampak tidak langsung adanya PMN adalah PT Waskita mampu menambah aset-aset produktifnya sehingga aset tersebut juga dapat dimanfaatkan untuk menambah profit Waskita. Maka dari itu, bisa jadi dampak adanya PMN ini baru dapat dirasakan setelah beberapa tahun realisasinya.

Namun pada realitasnya, tahun 2017 merupakan tahun dimana pendapatan usaha PT Waskita mengalami kenaikan pertumbuhan yang sangat signifikan hingga 90\% dengan nilai Rp45,2 triliun yang pada tahun sebelumnya bernilai Rp23,7 triliun. Adanya kenaikan yang cukup besar ini tentunya tidak terlepas dari dana PMN yang digunakan PT Waskita untuk membangun tol di Jawa dan Sumatera pada tahun 2015. Pada tahun-tahun berikutnya, tentunya Waskita tetap melanjutkan proyek ini sehingga pada tahun 2017 PT Waskita Karya memiliki hak konsesi 18 ruas jalan tol dengan total Panjang $997 \mathrm{~km}$ yang tersebar di Pulau Jawa dan Sumatera.

\section{KESIMPULAN DAN SARAN}

\subsection{Kesimpulan}

Suntikkan dana melalui Penyertaan Modal Pemerintah (PMN) yang dilakukan oleh Pemerintah Pusat terhadap PT Waskita Karya menimbulkan beberapa dampak pada kinerja perusahaan. Berdasarkan perhitungan rasio keuangan berupa analisis terhadap Rasio Likuiditas, Rasio Solvabilitas, Rasio Aktivitas, Rasio Profitabilitas, dan signifikasi keuangannya, kinerja PT Waskita Karya setelah adanya PMN menunjukkan bahwa:
1. Rasio Likuiditas setelah dilakukannya PMN cenderung biasa saja, bahkan Current Ratio dan Acid Ratio tidak mengalami peningkatan pada tahun anggaran dilaksanakannya PMN. Hal sebaliknya terjadi pada Cash Ratio karena disaat rasio lain turun, Cash Ratio pada saat pelaksanaan PMN malah naik. Rasio Solvabilitas setelah adanya PMN langsung mengalami penurunan. Hal ini dikarenakan bertambahnya aset dan ekuitas Perusahaan Waskita karena adanya PMN. Dari segi Rasio Aktivitas, adanya PMN tentu membuat aset perusahaan bertambah sehingga rasionya mengalami penurunan. Namun seiring berjalannya waktu, perusahaan mulai mampu menaikkan angka rasionya kembali karena sudah mulai kapabel dan beradaptasi mengelola asetnya yang lebih banyak karena PMN tersebut. Sedangkan dampak implementasi PMN dari sisi Rasio Profitabilitas adalah terjadinya kenaikan angka di semua rasionya. Meskipun PMN tidak langsung terlibat dalam laporan laba rugi perusahaan, tentunya tambahan dana sebesar 3,5 triliun ini juga dapat dimanfaatkan perusahaan untuk kebutuhannya yang lain sehingga Waskita mampu meningkatkan pendapatan usahanya dari tahun ke tahun.

2. Ditinjau dari segi signifikansi, dampak adanya PMN bagi Perusahaan Waskita memang cukup membantu meningkatkan kinerja perusahaan. Namun karena Waskita juga merupakan BUMN besar dengan transaksi bisnis mencapai triliunan, maka nilai Rp3,5 triliun bisa dibilang biasa saja. Hal ini dapat dibuktikan melalui grafik rasio-rasio milik Perusahaan Waskita bahwa implementasi PMN hanya merubah sedikit pola grafik saja. Jadi dampaknya tidak terlalu signifikan untuk kebanyakan rasio. Tapi ternyata adanya PMN juga membuat perubahan yang sangat signifikan pada salah satu rasio, yakni Working Capital Turnover karena adanya kenaikan rasio sebesar lebih dari $13.000 \%$ dibandingkan tahun sebelumnya.

\section{IMPLIKASI DAN KETERBATASAN}

PMN merupakan salah satu cara pemerintah untuk menyehatkan suatu BUMN atau badan usaha lainnya. Meskipun jumlah PMN yang diberikan kepada PT Waskita Karya cukup besar, tentunya perubahan rasio tidak hanya disebabkan oleh adanya aktivitas PMN semata, melainkan ada aktivitas lain dari perusahaan yang ikut terlibat. Maka dari itu, selain melihat adanya PMN, Penulis juga mencoba mengamati aktivitas lain dari perusahaan yang sekiranya juga ikut menyebabkan terjadinya perubahan rasio yang cukup signifikan.

\section{DAFTAR PUSTAKA}

\section{Buku dan atau Sumber Lainnya}


Dinarjito, A. (2019). Penyertaan Modal Negara Pertumbuhan Aset dan Kinerja Badan Usaha Milik Negara. E-Jurnal Akuntansi, 1323-1345.

CNBC Indonesia. (2020, Februari 19). CNBC News. Diakses dari situs resmi CNBC Indonesia: https://www.cnbcindonesia.com/news/2020 0219184013-4-139126/curhat-seorang-dirutbumn-sudah-merugi-seperempat-abad

Kasmir \& Jakfar (2012). Studi Kelayakan Bisnis Edisi Revisi. Jakarta: Prenadamedia Group.

Katadata. (2020, Mei 15). Berita Bisnis. Diakses dari situs resmi Katadata: https://katadata.co.id/happyfajrian/berita/5e be5d3fee1c8/tiga-skenario-pemerintahselamatkan-bumn-dari-pandemi-corona

Katadata. (2021, Juli 15). Finansial Korporasi. Diakses dari situs resmi Katadata: https://katadata.co.id/lavinda/finansial/60eff d0733101/menakar-dana-jumbo-pmn-untukwaskita-agar-keluar-dari-tumpukan-utang

Kompas. (2021, Maret 5). Money.Kompas. Diakses dari situs resmi Kompas: https://money.kompas.com/read/2021/03/0 5/204910626/mengenal-bumn-definisi-jenisfungsi-dan-tujuan-didirikan?page=all

Kumparan. (2021, Februari 3). Berita Update. Diakses dari situs resmi Kumparan: https://kumparan.com/berita-update/fungsipengertian-dan-jenis-rasio-keuangan1v6PWp7GHWW/1

Orniati, Y. (2009). Laporan Keuangan sebagai Alat untuk Menilai Kinerja Keuangan. Jurnal Ekonomi dan Bisnis, 206-217.

Pemerintah Republik Indonesia. (2015). Peraturan Pemerintah No.29 tahun 2015 tentang Penambahan Penyertaan Modal Negara Republik Indonesia ke dalam Modal Saham Perusahaan Perseroan (Persero) PT Waskita Karya Tbk. Jakarta: Sekretariat Negara.

Pemerintah Republik Indonesia. (2016). Peraturan Pemerintah No.72 tahun 2016 tentang Perubahan atas Peraturan Pemerintah No.44 tahun 2005 tentang Tata Cara Penyertaan dan Penatausahaan Modal Negara pada Badan Usaha Milik Negara dan Perseroan Terbatas. Jakarta: Sekretariat Negara.

PT Waskita Karya. (2013). Laporan Keuangan Tahunan. Jakarta: PT Waskita Karya
PT Waskita Karya. (2014). Laporan Keuangan Tahunan. Jakarta: PT Waskita Karya

PT Waskita Karya. (2015). Laporan Keuangan Tahunan. Jakarta: PT Waskita Karya

PT Waskita Karya. (2016). Laporan Keuangan Tahunan. Jakarta: PT Waskita Karya

PT Waskita Karya. (2017). Laporan Keuangan Tahunan. Jakarta: PT Waskita Karya

Sugiyono. (2017). Metode Penelitian Kuantitatif, Kualitatif, dan R\&D. Bandung: CV Alfabeta.

Titman, Sheridan, Arthur J. Keown, \& John D. Martin. (2018). Financial Management Principles and Applications Thirteen Edition. Harlow:Pearson Education

UNM. (2018, April 8). Penelitian Deskriptif Kuantitatif. 


\section{ILUSTRASI TABEL}

Ikhtisar Keuangan PT Waskita Karya tahun 2013 - 2017 (dalam miliar rupiah)

\begin{tabular}{|c|c|c|c|c|c|}
\hline & 2013 & 2014 & 2015 & 2016 & 2017 \\
\hline Persediaan & 292,23 & 604,28 & 826,38 & 2556,73 & 3235,5 \\
\hline Kas atau setara kas & 1119,69 & 1675,28 & 5511,19 & 10653,78 & 6088,96 \\
\hline \multicolumn{6}{|l|}{ Aset lancar lainnya (Formalitas) } \\
\hline Total Aset Lancar & 7698,33 & 10104,98 & 15805,62 & 39712,58 & 52427,02 \\
\hline Aset Tetap (Fixed Assets) & 415,44 & 621,79 & 1923,14 & 3013,85 & 4742,29 \\
\hline \multicolumn{6}{|l|}{ Aset tidak lancar lainnya (Formalitas) } \\
\hline Total Aset Tidak Lancar & 1089,97 & 2437,06 & 14503,49 & 21720,44 & 45468,74 \\
\hline Total Aset & 8788,3 & 12542,04 & 30309,11 & 61433,02 & 97895,76 \\
\hline Liabilitas Jangka Pendek & 5427,14 & 7728,15 & 13631,23 & 31283,65 & 52309,19 \\
\hline Liabilitas Jangka Panjang & 1036,41 & 2048,91 & 6973,67 & 13376,14 & 22831,74 \\
\hline Jumlah Liabilitas & 6463,55 & 9777,06 & 20604,9 & 44659,79 & 75140,93 \\
\hline Jumlah Ekuitas & 2342,76 & 2764,98 & 9704,21 & 16773,22 & 22754,82 \\
\hline Jumlah Liabilitas dan ekuitas & 8788,3 & 12542,04 & 30309,11 & 61433,02 & 97895,76 \\
\hline Modal kerja Bersih (Net Working Capital) & 2271,19 & 2376,83 & 2174,39 & 8428,93 & 117,83 \\
\hline \multicolumn{6}{|l|}{ Investasi pada Entitas } \\
\hline \multicolumn{6}{|l|}{ Aset Ventura Bersama } \\
\hline & 2013 & 2014 & 2015 & 2016 & 2017 \\
\hline Pendapatan Usaha (sales Revenue) & 9686,61 & 10286,81 & 14152,75 & 23788,32 & 45212,89 \\
\hline Beban Pokok Pendapatan & 8775,91 & 9177,92 & 12231,51 & 19820,48 & 35749,36 \\
\hline Laba Bruto (Gross Profit) & 910,7 & 1108,89 & 1921,24 & 3967,84 & 9463,53 \\
\hline $\begin{array}{l}\text { Laba Sebelum Pajak dan Beban Keuangan } \\
\text { (EBIT) }\end{array}$ & 706,9 & 949,74 & 1446,99 & 3145,78 & 6526,6 \\
\hline Laba Bersih Tahun Berjalan (Net Profit) & 367,97 & 511,57 & 1047,59 & 1813,07 & 4201,57 \\
\hline
\end{tabular}

